IOS Press

\title{
Review
}

\section{Dystroglycanopathies: About Numerous Genes Involved in Glycosylation of One Single Glycoprotein}

\author{
Céline Bouchet-Séraphin ${ }^{\mathrm{a}}$, Sandrine Vuillaumier-Barrot ${ }^{\mathrm{a}, \mathrm{b}}$ and Nathalie Seta ${ }^{\mathrm{a}, \mathrm{c}, *}$ \\ ${ }^{a}$ AP-HP, Hospital Bichat, Biochemistry, Paris, France \\ ${ }^{\mathrm{b}}$ INSERM U733, Bichat Faculty, Paris, France \\ ${ }^{\mathrm{c}}$ Université Paris Descartes, Paris, France
}

\begin{abstract}
Dystroglycanopathies are neuromuscular disorders due to abnormal glycosylation of dystroglycan which is a cellsurface glycoprotein that acts as a receptor for extracellular matrix proteins containing laminin-G domains. The reduced ability of abnormally glycosylated $\alpha-D G$ to bind laminin is associated with abnormal neuronal migration and muscular dystrophy. Clinical manifestations are extremely variable, and include a wide spectrum of phenotypic severity: some mutations are associated with adult-onset Limb-girdle muscular dystrophy and other mutations with a congenital onset, determining the more complex disorder Congenital Muscular Dystrophy which includes severe structural brain and eye anomalies such as Muscle-Eye-Brain Disease, Walker-Warburg Syndrome, and Fukuyama Congenital Muscular Dystrophy. So far, mutations in eighteen different genes have been identified in patients with dystroglycanopathies, all of them demonstrating autosomal recessive inheritance. Most genes code for glycosyltransferases (POMT1, POMT2, POMGNT1, LARGE, GTDC2, B4GAT1, B3GALNT2) although a minority does not (DPM1, DPM2, DPM3, DOLK, POMK, GMPPB). Others genes code for proteins of unknown function in the $\alpha$-dystroglycan glycosylation (FKTN, FKRP, ISPD, and TMEM5) or $\alpha$-dystroglycan itself, DAG1. The biochemical picture becomes a little bit more complete, but also more complex, with each new identified gene. In the majority of cases the identity of the defective gene cannot be predicted from the clinical phenotype. Considering the number of causative genes in dystroglycanopathies, targeted sequencing comprising genes of all glycosylation, whatever the type, would appear at present to be the best way of tackling molecular diagnosis.
\end{abstract}

Keywords: (4-10) MeSH database, glycosylation, O-mannosylation, CMD, LGMD, WWS

\section{ABBREVIATIONS}

\section{Sugars}

Dol-P-Man

Gal

GalNAc

GlcNAc

GlcA

Man dolichol phosphate mannose

galactose

$\mathrm{N}$-acetylgalactosamine

$\mathrm{N}$-acetylglucosamine

glucuronic acid

mannose

$\begin{array}{ll}\text { NeuAc } & \text { neuraminic acid } \\ \text { Xyl } & \text { xylose }\end{array}$

Others

*Correspondence to: Prof Nathalie Seta, Laboratoire de biochimie, Hôpital Bichat, 46 rue Henri Huchard, 75018 Paris, France. Tel.: +33 1402585 43; Fax: +33 1402588 21; E-mail: nathalie.seta@bch.aphp.fr.
CDG

CMD

DGpathy

FCMD

LGMD

LIS II

congenital disorders of glycosylation congenital muscular dystrophy dystroglycanopathy Fukuyama Congenital Muscular Dystrophy Limb-girdle muscular dystrophy lissencephaly type II or cobblestone lissencephaly

MEB Muscle-Eye-Brain Disease

WWS Walker-Warburg Syndrome

$\alpha-\mathrm{DG} \quad \alpha$-dystroglycan 


\section{INTRODUCTION}

$\alpha$-dystroglycanopathies represent a group of genetic disorders related with glycosylation defects of one specific glycoprotein, $\alpha$-dystroglycan ( $\alpha$-DG).

Dystroglycan encoded by a single gene, DAG1 [1], is part of the dystrophin-glycoprotein complex that serves to connect the actin cytoskeleton with the extracellular matrix [2]. In order to fulfil its functions, dystroglycan requires extensive post-translational processing, into two subunits [3]: $\beta$-dystroglycan which is anchored to the dystrophin complex and spans the sarcolemma; $\alpha$-DG, a cell-surface glycoprotein which binds to $\beta$-dystroglycan on the extracellular side and acts as a receptor for extracellular matrix proteins containing laminin-G domains [4] such as laminin at the sarcolemma (Fig. $1 \mathrm{~A}$ ), neurexin in the brain, and agrin at the neuromuscular junction. It thus plays important roles in sarcolemmal and basement membrane stability and neuronal cell migration, as well as performing other putative functions [5]. Dystroglycan is widely expressed and heavily glycosylated [6], and the reduced ability of abnormally glycosylated $\alpha-D G$ to bind laminin is associated with abnormal neuronal migration and muscular dystrophy [7].

Mutations in genes required for $\alpha-D G$ glycosylation lead to neuromuscular disorders, called dystroglycanopathies (DGpathies), a clinical and genetically heterogeneous subgroup of muscular dystrophies [8]. A reduction in glycosylated $\alpha-D G$ associated with reduced binding to laminin is the hallmark of these conditions. The glycosylation status of $\alpha$-DG is normally assessed by the binding of the $\alpha$-DG antibody IIH6 to a specific glycan epitope on $\alpha$-DG involved in laminin binding [4].

Clinical manifestations are extremely variable, and include a wide spectrum of phenotypic severity. Although genotype-phenotype correlations initially suggested a strong association between the first two identified genes (POMGNT1 and FKTN) and a specific phenotype $[9,10]$, it later became clear that no such tight association could be defined. All genes involved in DGpathies show a phenotypic divergence, with some mutations associated with adult-onset Limb-girdlemuscular dystrophy (LGMD), and other ones with a congenital onset, determining the more complex disorder Congenital Muscular Dystrophy (CMD) or indeed even more dramatic conditions such as severe structural brain and eye anomalies (Muscle-Eye-Brain Disease - MEB/OMIM 253280, Walker-Warburg Syndrome - WWS/OMIM 236670, Fukuyama Congenital Muscular Dystrophy - FCMD/OMIM 253800) [8].
Prenatal brain imaging can identify a severe form with early onset, cobblestone lissencephaly (LIS II), highly evocative of DGpathies [11]. Finally, the most severe end of the spectrum may be early embryonic lethality as supported by KO mouse models of dystroglycan [12], fukutin [13], Pomt1 [14], B3gntl [15] and Fkrp gene deficiency [16].

So, $\alpha-D G$ glycosylation plays a crucial role in its different functions. $\alpha-D G$ contains $\mathrm{N}$-glycans, and O-glycans of two types in the mucin-like domain: O-acetylgalactosaminyl (GalNAC) and Omannosyl (Man) initiated glycans [17]. Compared to the largely explored N-glycosylation or even other Oglycosylation pathways, O-mannosylation, although being an evolutionarily conserved post-translational modification from yeast to man, is however confidential and restricted to only very few mammalian glycoproteins, including $\alpha$-DG [18]. Since the lamininbinding property was shown to be linked to $\alpha$-DG O-Man glycans [19], we will focus on them.

\section{$\alpha$-DYSTROGLYCAN O-MANNOSYLATED GLYCANS}

The two following O-Man structures (Fig. $1 \mathrm{~B}$ and C) have been described in $\alpha-\mathrm{DG}$, and called M1 and M3, respectively, according to the nomenclature recently introduced by Yoshida-Moriguchi et al. [20].

- Classical NeuAc- $\alpha 2,3-G a l-\beta 1,4-G l c N a c-\beta 1,2-$ Man- $\alpha 1-S e r / T h r$, which can have branches at the C-6 of Man (M1 when unbranched (Fig. 1B) and M2 when branched). This tetrasaccharide is found in high abundance in $\alpha-D G$ of the muscle and brain, but is not the laminin-binding moiety: glycosidase-mediated removal of all or most of the three sugars at the non-reducing terminus does not reduce $\alpha-\mathrm{DG}$ binding to laminin [21].

- Partially and newly characterised GalNAc- $\beta 1,3-$ GlcNAc- $\beta 1,4-[6-p h o s p h o r y l]-M a n-\alpha 1-S e r / T h r$, (M3; Fig. 1C), found in a limited amount in $\alpha-\mathrm{DG}$, is essential for laminin [20] and Arenavirus binding [22]. Extension of the phosphodiester in 3 is required for laminin binding but may not occur in all tissues [23]. This ligand binding structure is not fully known, but includes a polysaccharide based on a repeat of xylose (Xyl) and glucuronic acid (GlcA). It is not clear whether there is any terminal modification [24]. 


\section{GENES ASSOCIATED WITH DYSTROGLYCANOPATHIES}

Abnormal synthesis of the peptide chain in relation with mutations in the gene coding for dystroglycan, DAG1 (OMIM 128239), represents primary DGpathy with up until now a limited number of patients, only four reported individuals [25-27]. Note that these patients showed muscle muscular dystrophy and hypoglycosylation of $\alpha-\mathrm{DG}$, indicating that $\alpha-\mathrm{DG}$ glycosylation was indirectly affected [26].

Abnormal O-glycosylation of $\alpha-D G$ causes secondary DGpathies, which are thus associated with mutations in genes coding for proteins involved in its glycosylation pathway. So far, mutations in seventeen different genes have been identified in patients with a DGpathy, all of them demonstrating autosomal recessive inheritance. Historically, six genes (POMT1, POMT2, POMGNT1, FKTN, FKRP and LARGE) were identified during a long period that stretched from 1989 [9] to 2011. Then, thanks to the use of next generation sequencing in the late two thousands, a large number of additional genes were reported.

Some of these genes code for enzymes known to be involved in the O-mannosylation pathway [28], whilst others code for proteins of unknown function in $\alpha-$ DG glycosylation. Genes specifically coding for glycosyltransferases presently dominate in the molecular landscape of DGpathies.

In this review, genes coding for proteins related with the two different types of O-mannosyl glycans will be successively presented, followed by genes whose function is up until now unknown, and finally those genes involved in Man metabolism (Table 1).

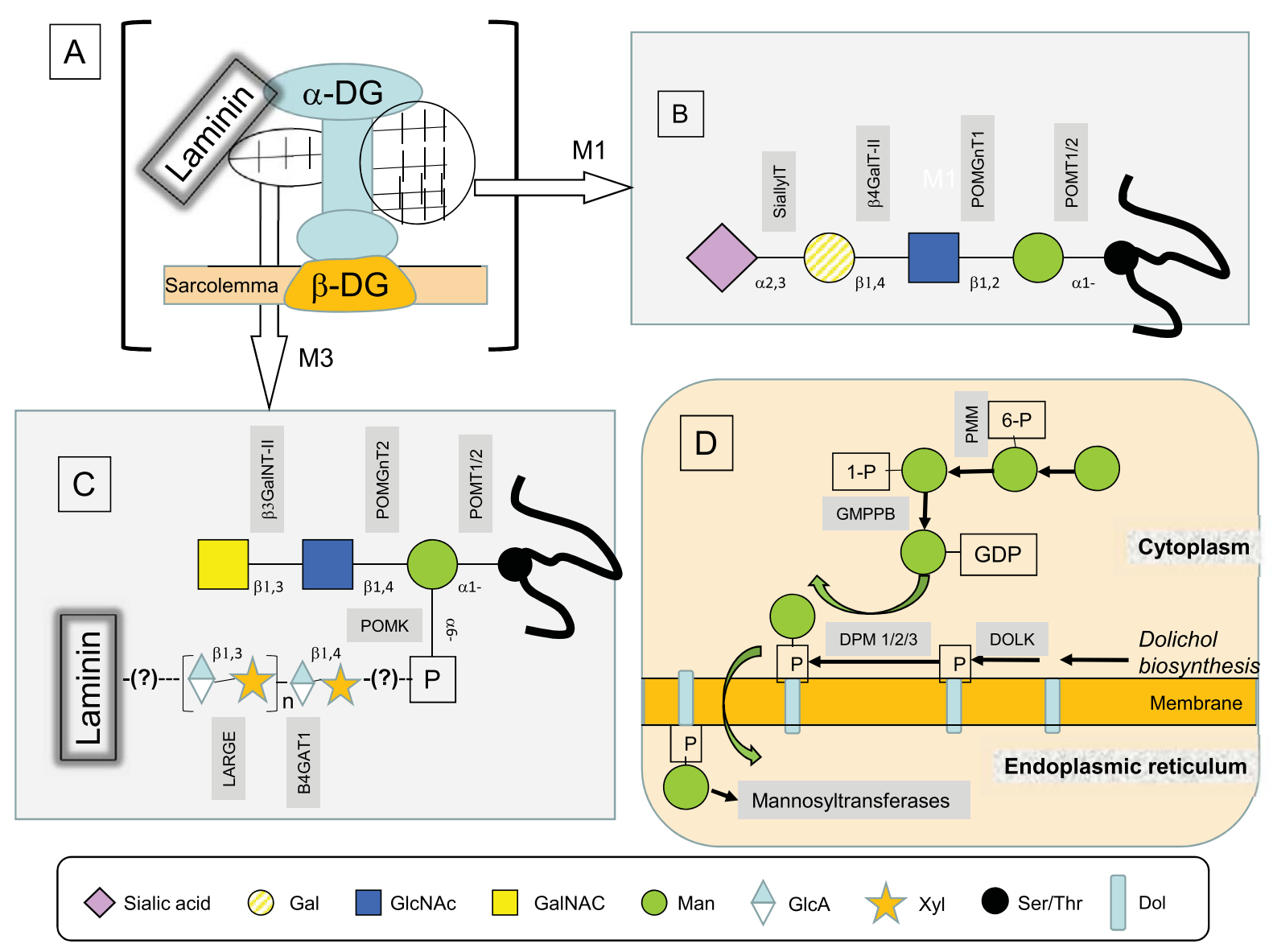

Fig. 1. $\alpha$-dystroglycan O-mannosylation (partly adapted from [2]). A: Dystrophin-glycoprotein complex. B and C: O-mannosylated glycan structures of $\alpha$-dystroglycan showing sugar residues (conventional annotation) Man (green circle), Gal (shaded yellow circle), GlcNAc (blue square), GalNAc (yellow square), sialic acid (purple diamond), Xyl (orange star), GlcA (blue/white diamond), Ser/Thr (black circle). Catalysing enzymes (grey background). B: NeuAc-a2,3-Gal-b1,4-GlcNac-b1,2-Man-a1-Ser/Thr (M1). C: GalNAc-b1,3-GlcNAc-b1,4-[6phosphoryl]-Man-a1-Ser/Thr (M3). D: Dolichol (light blue rectangle) and mannose metabolic pathway leading to Dol-P-Man, substrate of mannosyltransferases. 
Genes associated with abnormal M1 and M2 $O$-glycan structure are POMT1 and POMT2, and POMGNT1

\section{- POMT1 (OMIM 607423) and POMT2 (OMIM 607439)}

POMT1 and POMT2 form an enzyme complex, POMT (Protein O-mannosyltransferase), that adds the first sugar, Man coming from Dol-P-Man as the donor, to serine or threonine of the peptide chain. Initial Omannosylation occurs in the endoplasmic reticulum. These two proteins are the key for O-mannosylated glycans, whatever their structure (M1, M2, M3) (Fig. 1 B and C).

Both encountered genes, POMT1 and POMT2, are frequently implicated in DGpathies. Most patients bearing mutations on them present with a severe form of DGpathy with mental retardation: foetal LIS II [29] and WWS [30, 31], but also MEB [32, 33]. However, POMT1 or POMT2 mutations have been found in several patients with mental retardation, with less severe CMD [34] and even LGMD $[33,35]$.

\section{- POMGNT1 (OMIM 606822)}

POMGnT1 catalyses the $\beta-1,2$ linkage of $\mathrm{N}$ acetylglucosamine (GlcNAc) to the O-mannosyl residue already attached to the peptide chain (Fig. 1B) [36]. It is localized in cis-Golgi and acts prior to the other possible extension on O-mannose catalysed by a $\mathrm{N}$-acetyglucosaminyltransferase, GnT-Vb also known as GnT-IX, specifically expressed in the brain [37], and leading to a branched glycan (M2).

POMGNT1 mutations were firstly described in an isolated Finnish population in association with MEB [9]. POMGNT1 mutations are finally found worldwide, as the other genes related with DGpathies, and have so far been described in patients with clinical features of MEB and less severe CMD [33,38], as well as in foetal LIS II cases [29].

The other glycosyltransferases leading to the M1 and M2 glycan structures have not been implicated in DGpathy to date.

Genes associated with abnormal M3 O-glycan structure are GTDC2, B3GALNT2 and SGK196, and to a lesser extent, LARGE and B4GAT1 (in addition to POMT1 and POMT2).

The identification of mutations on these three genes associated with DGpathies has enabled a new glycan structure to be elucidated (M3; Fig. 1C), which is required for downstream modification by LARGE and $\beta 4$ GAT1 activity.

\section{- GTDC2 (OMIM 614828)}

The protein POMGnT2 encoded by GTDC2 (alternatively called AGO61 or POMGNT2) localises in the endoplasmic reticulum. It is a glycosyltransferase that catalyses the $\beta-1,4$ linkage of a GlcNAc to the Omannosyl residue already attached to the peptide chain [20] just as POMGnT1, the difference lying in the type of linkage.

Prior to the comprehensive understanding of its function, exome sequencing of individuals from consanguineous families identified three families whose individuals all presented with WWS [39].

\section{- B3GALNT2 (OMIM 610194)}

The protein $\beta 3$ GalNT2 encoded by B3GALNT2 localises in the endoplasmic reticulum. It is a glycosyltransferase that transfers $\mathrm{N}-$ GalNAc in a $\beta-1,3$ linkage to the second sugar of the M3 glycan, N-GlcNAc.

Mutations in B3GALNT2 were found in two individuals from one cohort, followed by five additional cases that were all affected by DGpathy with structural brain involvement $[40,41]$. The activity of the protein encoded by B3GALNT2 was at that time deduced from its structure but the structure in which it was involved in was not [42].

\section{- SGK196 (OMIM 615247)}

Protein O-mannose kinase (POMK) is the protein encoded by $S G K 196$ (or POMK). It is one of the proteins involved in DGpathies with a known function that is not a glycosyltransferase. It phosphorylates the O-mannose at its 6-position, of the M3 glycan serving as substrate recognition motif of POMK [20]. This glycosylation-specific kinase transfers the phosphodiester that is required to assemble the laminin-binding moiety [23]. POMK needs for acceptor the whole M3 trisaccharide [20] which clarifies, why mutations in GTDC2 and B3GALNT2 are associated with DGpathies.

Six individuals from four families with DGpathy with mutations in $S G K 196$ were very recently reported [43-45], presenting with different clinical manifestations ranging from WWS to LDMD.

\section{- LARGE (OMIM 603590)}

LARGE directly participates in the postphosphorylation biosynthetic pathway. This enzyme contains two glycosyltransferase domains and builds the repeated disaccharide, 3 Xyl- $\alpha 1,3-$ GlcA- $\beta 1$ which 
is bound to $\alpha-D G$ through the rare M3 structure at the amino terminus of its mucin-like domain, phosphorylated 6-mannosyl glycan [46]. The presence and even more importantly the number of repeats of this disaccharide is essential for binding to extracellular matrix proteins [24]. $\alpha-$ DG molecular mass variability during myogenesis is due to differences in the quantity of disaccharide repeats, not attributable to the addition of $\alpha-D G$ glycans but rather as a consequence of extension of the glycan present [24]. However, the precise cellular function of the repeated disaccharide is still unknown [24]. LARGE close homologue, LARGE2 (also named GYLTL1B, OMIM 609709) catalyses the same reaction as LARGE [47].

Mutations in LARGE (so called because of its size), first reported in 2003 [48], have been found in foetal cases [49] as well as in individuals, 15 patients with different clinical presentations from 12 families [50, 51], contrary to LARGE2 which has never been described as mutated.

\section{- B4GAT1 (OMIM 605517)}

B4GAT1 (formerly B3GNT1) encodes a Xyl$\beta 1,4$-glucuronyltransferase which synthesises the disaccharide Xyl- $\beta 1,4-G l c A$ that serves as an acceptor primer that can be elongated by LARGE with Xyl$\beta 1,3-$ GlcA repeated disaccharide (Fig. 1C) [52, 53].

Its role in the glycosylation pathway of $\alpha-D G$ was not defined when mutations in B4GATl were associated with WWS in individuals from two different families [54, 55]. It is presently considered as a rare cause of severe DGpathy, until other cases are reported.

The following genes encode for proteins with unknown function in glycosylation of $\alpha-D G$

\section{- FKTN (OMIM 607440) and FKRP (OMIM 606596)}

Mutations in FKTN are responsible for the high prevalence of FCMD in Japan, because of an ancestral founder mutation arising from the insertion of a $3 \mathrm{~kb}$ retrotransposon into the 3' untranslated region (carrier frequency of this mutation: 1 in 88) shared by more than $80 \%$ of Japanese patients [10]. Indeed, in Japan, FCMD is the second most frequent congenital muscular dystrophy after Duchenne muscular dystrophy [10]. However, although mutations in FKTNhave been shown ascausativeinFCMDsincemore than adecade, the activity of the encoded protein, fukutin, localized in the Golgi is stillunknown. Mutationin FKTNappears toresultboth in misfolding of fukutin and its mislocalization, along with POMGnT1, thus supporting the hypothesis that it functions as a chaperon for the latter [56].

Outside of Japan where hundreds of FCMD patients with FKTN mutations (different from the one found frequently in Japan) have been diagnosed, FKTN is much less frequently encountered in DGpathies $[33,38,57]$. It was never found in foetal LIS II cases [29].

Fukutin Related Protein (FKRP) takes its name from the high homology to fukutin. Just as for fukutin, the role of FKRP is unknown and could be considered as a putative Golgi-localized glycosyltransferase [58, 59].

FKRP was first implicated in DGpathies in 2001 [60]. Mutation in the FKRP gene can cause the three different forms of DGpathies: however, most patients present with the mildest forms (LGMD2I) and FKRP is the most frequent causative gene in adult patients with DGpathy. In general, the more severe phenotypes appeared to be associated with mutations predicted to result in severe disruption of the gene [38, 61, 62]. Mutations in FKRP were also identified in WWS [61] and one foetal LISS II case [11]. Finally, although numerous mutations in FKRP have been identified, a majority of LGMD2I patients bear the frequent mutation c.826C > A (p.Leu276Ile) [60, 63-65].

\section{- ISPD (OMIM 614631)}

Mutations in $I S P D$, the isoprenoid synthase domain containing gene, are a frequent cause of DGpathy, as reported after the simultaneous and independent identification by different teams [66-68]. The function of the protein encoded by this gene is still unknown. Vegetal orthologs of ISPD are part of the methylerythritol pathway. This mevalonate-independent pathway is absent in mammals, which suggests that ISPD must have a different function in humans [69]. Expression of wild type $I S P D$ in patient-derived cells restored functional glycosylation, confirming that the mutations have pathogenic relevance. Studies of skeletal muscle and fibroblasts from patients showed a typical $\alpha-D G$ glycosylation defect, with loss of both functional glycosylation and laminin binding, by disrupting $\alpha$-DG O-mannosylation. Indeed, O-mannosyl phosphorylation and LARGE-dependent glycosylation were absent [66], indicating that ISPD function is crucial for efficient POMT-dependent Omannosylation of $\alpha-\mathrm{DG}$.

More than twenty-five individuals have been reported, evenly distributed from the most severe clinical presentation, LIS II [68] and WWS [66, 70], to milder forms such as LGMD [71, 72]. 
Table 1

Genes and encoded proteins involved in $\alpha$-dystroglycanopathies

\begin{tabular}{|c|c|c|c|}
\hline Gene & & $\begin{array}{c}\text { Encoded protein } \\
\text { (abbreviation/full name) }\end{array}$ & $\begin{array}{l}\text { Function of } \\
\text { the protein }\end{array}$ \\
\hline \multicolumn{4}{|c|}{ Primary $\alpha$-dystroglycanopathy } \\
\hline$D A G 1$ & Dystroglycan & & \\
\hline \multicolumn{4}{|c|}{ Secondary $\alpha$-dystroglycanopathy } \\
\hline POMT1 & POMT1 & Protein O-mannosyl transferase 1 & Glycosyl transferase \\
\hline POMT2 & POMT2 & Protein O-mannosyl transferase 2 & Glycosyl transferase \\
\hline POMGNT1 & POMGnT1 & $\begin{array}{l}\text { Protein O-mannosyl N-acetyglucos- } \\
\text { aminyltransferase } 1\end{array}$ & Glycosyl transferase \\
\hline $\begin{array}{l}\text { GTDC2 (alias AGO61, } \\
\text { POMGNT2) }\end{array}$ & POMGnT2 & $\begin{array}{l}\text { Protein O-mannosyl N-acetyglucosam- } \\
\text { inyltransferase } 2\end{array}$ & Glycosyl transferase \\
\hline$B 3 G A L N T 2$ & $\beta 3$ GalNT2 & $\begin{array}{l}\text { UDP-GalNAc:GlcNAc: } \\
\beta-1,3-N \text {-acetylgalactosaminyltransferase } 2\end{array}$ & Glycosyl transferase \\
\hline \multicolumn{4}{|c|}{ 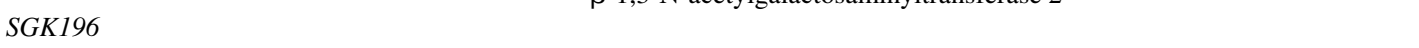 } \\
\hline $\begin{array}{l}\text { (alias POMK) } \\
\text { LARGE }\end{array}$ & $\begin{array}{l}\text { POMK } \\
\text { LARGE }\end{array}$ & $\begin{array}{l}\text { Protein O manosyl kinase } \\
\text { UDP-Xyl:GlcA } \alpha-1,3 \text {-xylosyltransferase/ } \\
\text { UDPGlcA:Xyl } \beta-1,3 \text {-glucuronosyltransferase }\end{array}$ & $\begin{array}{l}\text { Glycosyl transferase } \\
\text { Glycosyl transferase }\end{array}$ \\
\hline \multicolumn{4}{|c|}{ 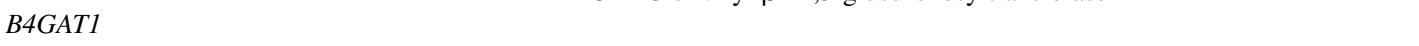 } \\
\hline$(e x-B 3 G N T 1)$ & $\beta 4 \mathrm{GAT} 1$ & UDP-Xyl- $\beta 1,4$-glucuronyltransferase & Glycosyl transferase \\
\hline FKTN & FKTN & fukutin & Unknown \\
\hline FKRP & FKRP & Fukutin-related protein & Unknown \\
\hline$I S P D$ & ISPD & isoprenoid synthase domain containing protein & Unknown \\
\hline TMEM5 & TMEM5 & Type II transmembrane protein 5 & Unknown \\
\hline GMPPB & GMPPB & GDP-mannose pyrophosphorylase B & Transferase \\
\hline$D P M 1$ & DPM1 & Subunits of Dol-P-Man synthase & \\
\hline DPM2 & DPM2 & complex & Transferase \\
\hline DPM3 & DPM3 & & \\
\hline$D O L K$ & DOLK & dolichol kinase & Kinase \\
\hline
\end{tabular}

\section{- TMEM5 (OMIM 605862)}

TMEM5 encodes a type II transmembrane protein localized in the Golgi apparatus [53] and that has not been assigned any function. Interestingly, it contains an exostosin family domain, also present in EXT1 and EXT2, both genes involved in hereditary multiple exostose (OMIM 133700), another O-glycosylation disorder [73]. EXT1 codes for glycosyltransferase, required for the biosynthesis of heparin sulphate, and a putative tumour suppressor gene. Note that three out of the five TMEM5 mutations identified in foetal LIS II cases were also located in the exostosin domain. TMEM5 could therefore be a transmembrane protein with a glycosyltransferase function [68].

TMEM5 was found mutated in nine foetal LIS II cases [68] and individuals from two families [43].

Genes involved in mannose and dolichol metabolisms are GMPPB, DPM1/2/3 and DOLK

Finally, some patients with a-DGpathies bear mutations in genes involved in Man and Dolichol metabolism, both essential for the synthesis of DolP-Man. Dol-P-Man is the sugar donor of Man for mannosyltransferases working in the endoplasmic reticulum, i.e. the ones of $\mathrm{N}$-glycosylation, and $\mathrm{O}$ mannosylation.

\section{- DPM1 (OMIM 603503), DPM2 (OMIM 603564), DPM3 (OMIM 605951), DOLK (OMIM 610746)}

These four genes code for major enzymes implicated in Dol metabolism. Dol-P-Man synthesis is catalysed by the Dol-P-Man synthase complex (DPM) made of DPM1, DPM2 and DPM3, after phosphorylation of Dol by the dolichol kinase (DOLK) [74] (Fig. 1D).

Mutations in each of these four genes cause some Congenital Disorders of Glycosylation (CDG), a group of genetic diseases in which $\mathrm{N}$-glycosylation is altered, characterized by neurological involvement (predominantly, psychomotor retardation, epilepsy, hypotonia, hyporeflexia, strabismus, polyneuropathy, and cerebellar hypotrophy/hypoplasia), inconsistently associated with multisystemic involvement [75].

Interestingly, these four proteins, DPM1/2/3 and DOLK, have been recently related to DGpathies. Clinical presentation of the very few reported patients ranged from only muscular dystrophy (patient with DPM2 mutations; [76]) or dilated cardiomyopathy (patients with DOLK mutations; [77]) (patient with 
DPM1 mutations; [78]), to a superposition of both diseases, that is, muscular dystrophy and CDG signs (patient with DPM3 mutations; [79]).

- GMPPB (OMIM 615320)

GMPPB catalyses the synthesis of GDP-Man from GTP and Man-1-phosphate [80]. GDP-Man is the substrate of cytoplasmic mannosyltransferases required for the synthesis of the core N-glycan structure as well as for synthesis of Dol-P-Man (Fig. 1D).

Mutations in GMPPB have been reported in nine individuals from six families and are responsible for CMD and LGMD [81, 82].

Mutations in GMPPA (OMIM 615361) which codes for a related protein have recently also been linked to glycosylation disorder, characterized by achalasia, alacrima, and neurological defects [83]. Interestingly, none of the patients with GMPPA mutations presented with muscular dystrophy.

This is the first occurrence of combined protein Nglycosylation and $\alpha$-DGO-mannosylation deficiency in patients with mutations in genes related to the biosynthesis of Dol-P-Man.

A yet unexplained point is the variability of clinical presentation of patients with mutations in the same gene, from CDG to DGpathies, which leads to the question about the regulation of this metabolic crossroad.

Additionally the clinical discrepancy between $G M P P B$ and $P M M 2$ deficiency may stimulate questions about the metabolic role of GMPPB. Phosphomannomutase (PMM) is a cytosolic enzyme that catalyses the reversible conversion of Man 6-P to Man 1-P, which is then transformed into GDP-Man by GMPPB (Fig. 1D). Deficiency in PMM2 (OMIM 212065) is the typical and most common CDG, without any muscular signs [84] when deficiency in GMPPB is primarily related with muscular signs and never associated with CDG. An additional role for GMPPB has to be hypothesized.

\section{TACKLING THE MOLECULAR DIAGNOSIS OF DYSTROGLYCANOPATHIES}

Due to the absence of a worldwide/continent registry of DGpathies, the number of molecularly diagnosed patients is imprecise, possibly a few thousand worldwide. As always in genetic diseases, the local cumulative prevalence of DGpathies depends on carrier distribution and the degree of consanguinity. In any case there is a need to assess the prevalence of total DGpathies, and by each related gene.

However, not all of the patients with features of DGpathies carry mutations in any of the currently iden- tified causative genes. Indeed, over the past few years, a number of studies dealing with large cohorts of patients by different groups have established that a significant number of patients (from 20 to $50 \%$ ) are without a mutation in one of the currently known genes [33, 38, 68]. Apart from unidentified genes, the type of mutation can also be questioned. While point mutations are the most common mutation type in all DGpathy related genes, genomic or deletion-insertions have also been reported in particular in LARGE [49, 50, 85], POMT2 [34] and POMGNT1 [49]. These may be underdiagnosed as they are not always identified according to the techniques used.

The picture of DGpathies becomes a little bit more complete, but also more complex, with each new identified gene.

The high number of causative genes underlines the complex genotype-phenotype relation question. Indeed, none of the genes can be related with a single clinical presentation, since all are more or less linked to a variable severity of the presentation. When dealing with severity of presentation, the type of mutation must also be taken into account. Whereas truncating mutations POMT1 and POMT2, for example, are mostly found in foetal cases of LIS II [29], mutations found in children are essentially missense mutations (Bouchet C., unpublished data). Finally, the relation between laminin binding capacity of $\alpha-D G$ and clinical severity is also inconsistent as previously reported, whatever the method used to evidence this hypoglycosylation $[86,87]$, although POMT1 enzyme activity was shown to be inversely correlated with severity of the clinical phenotype of two patients with POMT1 mutations [88].

Hence, in the majority of cases the identity of the defective gene cannot be predicted from clinical phenotype. Considering the number of causative genes in DGpathies (and in CDGs), targeted sequencing comprising genes of all glycosylations, whatever the type, does at present appear to be the best way of tackling this molecular diagnosis.

Nevertheless, the last few years have seen an explosion in the number of genes involved in DGpathies $[68,81]$. This is in large part due to the proliferation of next generation sequencing techniques, which have enabled the relatively inexpensive and rapid sequencing of either whole exomes or genomes of affected families.

So far, $\alpha$-DGpathies have been related to abnormal glycosylation of $\alpha$-DG. The impact of the abnormal Omannosylation on the activity of other O-mannosylated proteins present in the brain, such as the major cadherin superfamily of cell membrane receptors [89] is still an 
unraised subject. Lommel et al. [90] have provided direct evidence that O-mannosylation is essential for E-cadherin-mediated cell adhesion. Consequently, the clinical presentation observed in $\alpha$-DG could also be related with other abnormally mannosylated glycoproteins present in the brain.

In conclusion, the metabolic complexity of DGpathies needs further investigation which, in addition to new genes identified in the future, will help us better understand the physiopathological mechanisms of DGpathies.

\section{ACKNOWLEDGMENTS INCLUDING SOURCES OF SUPPORT}

This work was supported by grant ERARE11-135 of the ERA-Net for Research Programs on Rare Diseases Joint Transnational Call 2011 (EURO-CDG).

\section{CONFLICT OF INTEREST}

The authors have no conflict of interest to report.

\section{REFERENCES}

[1] Ibraghimov-Beskrovnaya, O., Milatovich, A., Ozcelik, T., Yang, B., Koepnick, K., Francke, U., Campbell, K. P. Human dystroglycan: Skeletal muscle cDNA, genomic structure, origin of tissue specific isoforms and chromosomal localization. Hum Mol Genet. 1993; 2(10): 1651-1657.

[2] Henry, M. D., Campbell, K. P. Dystroglycan: An extracellular matrix receptor linked to the cytoskeleton. Curr Opin Cell Biol. 1996; 8(5): 625-631.

[3] Ervasti, J. M., Campbell, K. P. Membrane organization of the dystrophin-glycoprotein complex. Cell. 1991; 66(6): 11211131.

[4] Barresi, R., Campbell, K. P. Dystroglycan: From biosynthesis to pathogenesis of human disease. J Cell Sci. 2006; 119(Pt 2): 199-207.

[5] Martin, P. T. Dystroglycan glycosylation and its role in matrix binding in skeletal muscle. Glycobiology. 2003; 13(8): 55R66R.

[6] Durbeej, M., Henry, M. D., Campbell, K. P. Dystroglycan in development and disease. Curr Opin Cell Biol. 1998; 10(5): 594-601.

[7] Michele, D. E., Barresi, R., Kanagawa, M., Saito, F., Cohn, R. D., Satz, J. S., Dollar, J., Nishino, I., Kelley, R. I., Somer, H., Straub, V., Mathews, K. D., Moore, S. A., Campbell, K. P. Post-translational disruption of dystroglycan-ligand interactions in congenital muscular dystrophies. Nature. 2002; 418(6896): 417-422.

[8] Godfrey, C., Foley, A. R., Clement, E., Muntoni, F. Dystroglycanopathies: Coming into focus. Curr Opin Genet Dev. 2011; 21(3): 278-285.

[9] Santavuori, P., Somer, H., Sainio, K., Rapola, J., Kruus, S., Nikitin, T., Ketonen, L., Leisti, J. Muscle-eye-brain disease (MEB). Brain Dev. 1989; 11(3): 147-153.
[10] Kobayashi, K., Nakahori, Y., Miyake, M., Matsumura, K., Kondo-Iida, E., Nomura, Y., Segawa, M., Yoshioka, M., Saito, K., Osawa, M., Hamano, K., Sakakihara, Y., Nonaka, I., Nakagome, Y., Kanazawa, I., Nakamura, Y., Tokunaga, K., Toda, T. An ancient retrotransposal insertion causes Fukuyama-type congenital muscular dystrophy. Nature. 1998; 394(6691): 388-392.

[11] Devisme, L., Bouchet, C., Gonzales, M., Alanio, E., Bazin, A., Bessieres, B., Bigi, N., Blanchet, P., Bonneau, D., Bonnieres, M., Bucourt, M., Carles, D., Clarisse, B., Delahaye, S., Fallet-Bianco, C., Figarella-Branger, D., Gaillard, D., Gasser, B., Delezoide, A. L., Guimiot, F., Joubert, M., Laurent, N., Laquerriere, A., Liprandi, A., Loget, P., Marcorelles, P., Martinovic, J., Menez, F., Patrier, S., Pelluard, F., Perez, M. J., Rouleau, C., Triau, S., Attie-Bitach, T., VuillaumierBarrot, S., Seta, N., Encha-Razavi, F. Cobblestone lissencephaly: Neuropathological subtypes and correlations with genes of dystroglycanopathies. Brain. 2012; 135(Pt 2): 469-482.

[12] Williamson, R. A., Henry, M. D., Daniels, K. J., Hrstka, R. F., Lee, J. C., Sunada, Y., Ibraghimov-Beskrovnaya, O., Campbell, K. P. Dystroglycan is essential for early embryonic development: Disruption of Reichert's membrane in Dag1null mice. Hum Mol Genet. 1997; 6(6): 831-841.

[13] Kurahashi, H., Taniguchi, M., Meno, C., Taniguchi, Y., Takeda, S., Horie, M., Otani, H., Toda, T. Basement membrane fragility underlies embryonic lethality in fukutin-null mice. Neurobiol Dis. 2005; 19(1-2): 208-217.

[14] Willer, T., Prados, B., Falcon-Perez, J. M., Renner-Muller, I., Przemeck, G. K., Lommel, M., Coloma, A., Valero, M. C., de Angelis, M. H., Tanner, W., Wolf, E., Strahl, S., Cruces, J. Targeted disruption of the Walker-Warburg syndrome gene Pomt 1 in mouse results in embryonic lethality. Proc Natl Acad Sci U S A. 2004; 101(39): 14126-14131.

[15] Wright, K. M., Lyon, K. A., Leung, H., Leahy, D. J., Ma, L., Ginty, D. D. Dystroglycan organizes axon guidance cue localization and axonal pathfinding. Neuron. 2012; 76(5): 931-944.

[16] Chan, Y. M., Keramaris-Vrantsis, E., Lidov, H. G., Norton, J. H., Zinchenko, N., Gruber, H. E., Thresher, R., Blake, D. J., Ashar, J., Rosenfeld, J., Lu, Q. L. Fukutin-related protein is essential for mouse muscle, brain and eye development and mutation recapitulates the wide clinical spectrums of dystroglycanopathies. Hum Mol Genet. 2010; 19(20): 3995-4006.

[17] Live, D., Wells, L., Boons, G. J. Dissecting the molecular basis of the role of the O-mannosylation pathway in disease: Alpha-dystroglycan and forms of muscular dystrophy. Chembiochem. 2013; 14(18): 2392-2402.

[18] Stalnaker, S. H., Aoki, K., Lim, J. M., Porterfield, M., Liu, M., Satz, J. S., Buskirk, S., Xiong, Y., Zhang, P., Campbell, K. P., Hu, H., Live, D., Tiemeyer, M., Wells, L. Glycomic analyses of mouse models of congenital muscular dystrophy. J Biol Chem. 2011; 286(24): 21180-21190.

[19] Michele, D. E., Campbell, K. P. Dystrophin-glycoprotein complex: Post-translational processing and dystroglycan function. J Biol Chem. 2003; 278(18): 15457-15460.

[20] Yoshida-Moriguchi, T., Willer, T., Anderson ,M. E., Venzke, D., Whyte, T., Muntoni, F., Lee, H., Nelson, S. F., Yu, L., Campbell, K. P. SGK196 is a glycosylation-specific Omannose kinase required for dystroglycan function. Science. 2013; 341(6148): 896-899.

[21] Combs, A. C., Ervasti, J. M. Enhanced laminin binding by alpha-dystroglycan after enzymatic deglycosylation. Biochem J. 2005; 390(Pt 1): 303-309. 
[22] Cao W, Henry MD, Borrow P, Yamada H, Elder JH, Ravkov EV, Nichol ST, Compans RW, Campbell KP, Oldstone MB. Identification of alpha-dystroglycan as a receptor for lymphocytic choriomeningitis virus and Lassa fever virus. Science. 1998 Dec 11;282(5396):2079-2081.

[23] Yoshida-Moriguchi, T., Yu, L., Stalnaker, S. H., Davis, S., Kunz, S., Madson, M., Oldstone, M. B., Schachter, H., Wells, L., Campbell, K. P. O-mannosyl phosphorylation of alphadystroglycan is required for laminin binding. Science. 2010; 327(5961): 88-92.

[24] Goddeeris, M. M., Wu, B., Venzke, D., Yoshida-Moriguchi, T., Saito,F., Matsumura, K., Moore, S. A.,Campbell, K.P.LARGE glycans on dystroglycan function as a tunable matrix scaffold to prevent dystrophy. Nature. 2013; 503(7474): 136-140.

[25] Hara, Y., Balci-Hayta, B., Yoshida-Moriguchi, T., Kanagawa, M., Beltran-Valero de Bernabe, D., Gundesli, H., Willer, T., Satz, J. S., Crawford, R. W., Burden, S. J., Kunz, S., Oldstone, M. B., Accardi, A., Talim, B., Muntoni, F., Topaloglu, H., Dincer, P., Campbell, K. P. A dystroglycan mutation associated with limb-girdle muscular dystrophy. N Engl J Med. 2011; 364(10): 939-946.

[26] Geis, T., Marquard, K., Rodl, T., Reihle, C., Schirmer, S., von Kalle, T., Bornemann, A., Hehr, U., Blankenburg, M. Homozygous dystroglycan mutation associated with a novel muscle-eye-brain disease-like phenotype with multicystic leucodystrophy. Neurogenetics. 2013; 14(3-4): 205-213.

[27] Dong, M., Noguchi, S., Endo, Y., Hayashi, Y. K., Yoshida, S., Nonaka, I., Nishino, I. DAG1 mutations associated with asymptomatic hyperCKemia and hypoglycosylation of alphadystroglycan. Neurology. 2014. (Epub ahead of print).

[28] Wells, L. The o-mannosylation pathway: Glycosyltransferases and proteins implicated in congenital muscular dystrophy. J Biol Chem. 2013; 288(10): 6930-6935.

[29] Bouchet, C., Gonzales, M., Vuillaumier-Barrot, S., Devisme, L., Lebizec, C., Alanio, E., Bazin, A., Bessieres-Grattagliano, B., Bigi, N., Blanchet, P., Bonneau, D., Bonnieres, M., Carles, D., Delahaye, S., Fallet-Bianco, C., Figarella-Branger, D. Gaillard, D., Gasser, B., Guimiot, F., Joubert, M., Laurent, N., Liprandi, A., Loget, P., Marcorelles, P., Martinovic, J., Menez, F., Patrier, S., Pelluard-Nehme, F., Perez, M. J., RouleauDubois, C., Triau, S., Laquerriere, A., Encha-Razavi, F., Seta N. Molecular heterogeneity in fetal forms of type II lissencephaly. Hum Mutat. 2007; 28(10): 1020-1027.

[30] van Reeuwijk, J., Janssen, M., van den Elzen, C., BeltranValero, de Bernabe, D., Sabatelli, P., Merlini, L., Boon, M., Scheffer, H., Brockington, M., Muntoni, F., Huynen, M. A., Verrips, A., Walsh, C. A., Barth, P. G., Brunner, H. G., van Bokhoven, H. POMT2 mutations cause alpha-dystroglycan hypoglycosylation and Walker-Warburg syndrome. J Med Genet. 2005; 42(12): 907-912.

[31] Beltran-Valero, de Bernabe, D., Currier, S., Steinbrecher, A., Celli, J., van Beusekom, E., van der Zwaag, B., Kayserili, H., Merlini, L., Chitayat, D., Dobyns, W. B., Cormand, B., Lehesjoki, A. E., Cruces, J., Voit, T., Walsh, C. A., van Bokhoven, H., Brunner, H. G. Mutations in the Omannosyltransferase gene POMT1 give rise to the severe neuronal migration disorder Walker-Warburg syndrome. Am J Hum Genet. 2002; 71(5): 1033-1043.

[32] Mercuri, E., Topaloglu, H., Brockington, M., Berardinelli, A., Pichiecchio, A., Santorelli, F., Rutherford, M., Talim, B., Ricci, E., Voit, T., Muntoni, F. Spectrum of brain changes in patients with congenital muscular dystrophy and FKRP gene mutations. Arch Neurol. 2006; 63(2): 251-257.

[33] Godfrey, C., Clement, E., Mein, R., Brockington, M., Smith, J., Talim, B., Straub, V., Robb, S., Quinlivan, R., Feng, L.,
Jimenez-Mallebrera, C., Mercuri, E., Manzur, A. Y., Kinali, M., Torelli, S., Brown, S. C., Sewry, C. A., Bushby, K., Topaloglu, H., North, K., Abbs, S., Muntoni, F. Refining genotype phenotype correlations in muscular dystrophies with defective glycosylation of dystroglycan. Brain. 2007; 130(Pt 10): 2725-2735.

[34] Yanagisawa, A., Bouchet, C., Quijano-Roy, S., VuillaumierBarrot, S., Clarke, N., Odent, S., Rodriguez, D., Romero, N. B., Osawa, M., Endo, T., Taratuto, A. L., Seta, N., Guicheney, P. POMT2 intragenic deletions and splicing abnormalities causing congenital muscular dystrophy with mental retardation. Eur J Med Genet. 2009; 52(4): 201-206.

[35] Balci, B., Uyanik, G., Dincer, P., Gross, C., Willer, T., Talim, B., Haliloglu, G., Kale, G., Hehr, U., Winkler, J., Topaloglu, H. An autosomal recessive limb girdle muscular dystrophy (LGMD2) with mild mental retardation is allelic to WalkerWarburg syndrome (WWS) caused by a mutation in the POMT1 gene. Neuromuscul Disord. 2005; 15(4): 271-275.

[36] Yoshida, A., Kobayashi, K., Manya, H., Taniguchi, K., Kano, H., Mizuno, M., Inazu, T., Mitsuhashi, H., Takahashi, S., Takeuchi, M., Herrmann, R., Straub, V., Talim, B., Voit, T., Topaloglu, H., Toda, T., Endo, T. Muscular dystrophy and neuronal migration disorder caused by mutations in a glycosyltransferase, POMGnT1. Dev Cell. 2001; 1(5): 717-724.

[37] Inamori, K., Endo, T., Gu, J., Matsuo, I., Ito, Y., Fujii, S., Iwasaki, H., Narimatsu, H., Miyoshi, E., Honke, K., Taniguchi, N. N-Acetylglucosaminyltransferase IX acts on the GlcNAc beta 1,2-Man alpha 1-Ser/Thr moiety, forming a 2,6-branched structure in brain O-mannosyl glycan. J Biol Chem. 2004; 279(4): 2337-2340.

[38] Mercuri, E., Messina, S., Bruno, C., Mora, M., Pegoraro, E., Comi, G. P., D'Amico, A., Aiello, C., Biancheri, R., Berardinelli, A., Boffi, P., Cassandrini, D., Laverda, A., Moggio, M., Morandi, L., Moroni, I., Pane, M., Pezzani, R., Pichiecchio, A., Pini, A., Minetti, C., Mongini, T., Mottarelli, E., Ricci, E., Ruggieri, A., Saredi, S., Scuderi, C., Tessa, A., Toscano, A., Tortorella, G., Trevisan, C. P., Uggetti, C., Vasco, G., Santorelli, F. M., Bertini, E. Congenital muscular dystrophies with defective glycosylation of dystroglycan: A population study. Neurology. 2009; 72(21): 1802-1809.

[39] Manzini, M. C., Tambunan, D. E., Hill, R. S., Yu, T. W., Maynard, T. M., Heinzen, E. L., Shianna, K. V., Stevens, C. R., Partlow, J. N., Barry, B. J., Rodriguez, J., Gupta, V. A., AlQudah, A. K., Eyaid, W. M., Friedman, J. M., Salih, M. A., Clark, R., Moroni, I., Mora, M., Beggs, A. H., Gabriel, S. B., Walsh, C. A. Exome sequencing and functional validation in zebrafish identify GTDC2 mutations as a cause of Walker-Warburg syndrome. Am J Hum Genet. 2012; 91(3): 541-547.

[40] Stevens, E., Carss, K. J., Cirak, S., Foley, A. R., Torelli, S., Willer, T., Tambunan, D. E., Yau, S., Brodd, L., Sewry, C. A., Feng, L., Haliloglu, G., Orhan, D., Dobyns, W. B., Enns, G. M., Manning, M., Krause, A., Salih, M. A., Walsh, C. A., Hurles, M., Campbell, K. P., Manzini, M. C., Stemple, D., Lin, Y. Y., Muntoni, F. Mutations in B3GALNT2 cause congenital muscular dystrophy and hypoglycosylation of alpha-dystroglycan. Am J Hum Genet. 2013; 92(3): 354-365.

[41] Hedberg, C., Oldfors, A., Darin N. B3GALNT2 is a gene associated with congenital muscular dystrophy with brain malformations. Eur J Hum Genet. 2014; 22(5): 707-710.

[42] Hiruma, T., Togayachi, A., Okamura, K., Sato, T., Kikuchi, N., Kwon, Y. D., Nakamura, A., Fujimura, K., Gotoh, M., Tachibana, K., Ishizuka, Y., Noce, T., Nakanishi, H., Narimatsu, H. A novel human beta1, 
3-N-acetylgalactosaminyltransferase that synthesizes a unique carbohydrate structure, GalNAcbeta1-3GlcNAc. J Biol Chem. 2004; 279(14): 14087-14095.

[43] Jae, L. T., Raaben, M., Riemersma, M., van Beusekom, E., Blomen, V. A., Velds, A., Kerkhoven, R. M., Carette, J. E., Topaloglu, H., Meinecke, P., Wessels, M. W., Lefeber, D. J., Whelan, S. P., van Bokhoven, H., Brummelkamp, T. R. Deciphering the glycosylome of dystroglycanopathies using haploid screens for lassa virus entry. Science. 2013; 340(6131): 479-483.

[44] von Renesse, A., Petkova, M. V., Lutzkendorf, S., Heinemeyer, J., Gill, E., Hubner, C., von Moers, A., Stenzel, W., Schuelke, M. POMK mutation in a family with congenital muscular dystrophy with merosin deficiency, hypomyelination, mild hearing deficit and intellectual disability. J Med Genet. 2014; 51(4): 275-282.

[45] Di Costanzo, S., Balasubramanian, A., Pond, H. L., Rozkalne, A., Pantaleoni, C., Saredi, S., Gupta, V. A., Sunu, C. M., Yu, T. W., Kang, P. B., Salih, M. A., Mora, M., Gussoni, E., Walsh, C. A., Manzini, M. C. POMK mutations disrupt muscle development leading to a spectrum of neuromuscular presentations. Hum Mol Genet. 2014; 23(2): 5781-5792.

[46] Inamori, K., Yoshida-Moriguchi, T., Hara, Y., Anderson, M. E., Yu, L., Campbell, K. P. Dystroglycan function requires xylosyl- and glucuronyltransferase activities of LARGE. Science. 2012; 335(6064): 93-96.

[47] Inamori, K., Hara, Y., Willer, T., Anderson, M. E., Zhu, Z., Yoshida-Moriguchi, T., Campbell, K. P. Xylosyland glucuronyltransferase functions of LARGE in alphadystroglycan modification are conserved in LARGE2. Glycobiology. 2013; 23(3): 295-302.

[48] Longman, C., Brockington, M., Torelli, S., JimenezMallebrera, C., Kennedy, C., Khalil, N., Feng, L., Saran, R. K., Voit, T., Merlini, L., Sewry, C. A., Brown, S. C., Muntoni, F. Mutations in the human LARGE gene cause MDC1D, a novel form of congenital muscular dystrophy with severe mental retardation and abnormal glycosylation of alpha-dystroglycan. Hum Mol Genet. 2003; 12(21): 2853-2861.

[49] Vuillaumier-Barrot, S., Bouchet-Seraphin, C., Chelbi, M., Eude-Caye, A., Charluteau, E., Besson, C., Quentin, S., Devisme, L., Le Bizec, C., Landrieu, P., Goldenberg, A., Maincent, K., Loget, P., Boute, O., Gilbert-Dussardier, B., Encha-Razavi, F., Gonzales, M., Grandchamp, B., Seta, N. Intragenic rearrangements in LARGE and POMGNT1 genes in severe dystroglycanopathies. Neuromuscul Disord. 2011; 21(11): 782-790.

[50] Clarke, N. F., Maugenre, S., Vandebrouck, A., Urtizberea, J. A., Willer, T., Peat, R. A., Gray, F., Bouchet, C., Manya, H., Vuillaumier-Barrot, S., Endo, T., Chouery, E., Campbell, K. P., Megarbane, A., Guicheney, P. Congenital muscular dystrophy type 1D (MDC1D) due to a large intragenic insertion/deletion, involving intron 10 of the LARGE gene. Eur J Hum Genet. 2011; 19(4): 452-457.

[51] Meilleur, K. G., Zukosky, K., Medne, L., Fequiere, P., PowellHamilton, N., Winder, T. L., Alsaman, A., El-Hattab, A. W., Dastgir, J., Hu, Y., Donkervoort, S., Golden, J. A., Eagle, R., Finkel, R., Scavina, M., Hood, I. C., Rorke-Adams, L. B., Bonnemann, C. G. Clinical, pathologic, and mutational spectrum of dystroglycanopathy caused by LARGE mutations. J Neuropathol Exp Neurol. 2014; 73(5): 425-441.

[52] Praissman, J. L., Live, D. H., Wang, S., Ramiah, A., Chinoy, Z. S., Boons, G. J., Moremen, K. W., Wells, L. B4GAT1 is the priming enzyme for the LARGE-dependent functional glycosylation of alpha-dystroglycan. Elife. 2014; 3 .
[53] Willer, T., Inamori, K., Venzke, D., Harvey, C., Morgensen, G., Hara, Y., Beltran Valero de Bernabe, D., Yu, L. Wright, K. M., Campbell, K. P. The glucuronyltransferase B4GAT1 is required for initiation of LARGE-mediated alphadystroglycan functional glycosylation. Elife. 2014; 3 .

[54] Buysse, K., Riemersma, M., Powell, G., van Reeuwijk, J., Chitayat, D., Roscioli, T., Kamsteeg, E. J., van den Elzen, C., van Beusekom, E., Blaser, S., Babul-Hirji, R., Halliday, W., Wright, G. J., Stemple, D. L., Lin, Y. Y., Lefeber, D. J., van Bokhoven, H. Missense mutations in beta-1,3-N-acetylglucosaminyltransferase 1 (B3GNT1) cause Walker-Warburg syndrome. Hum Mol Genet. 2013; 22(9): 1746-1754.

[55] Shaheen, R., Faqeih, E., Ansari, S., Alkuraya, F. S. A truncating mutation in B3GNT1 causes severe Walker-Warburg syndrome. Neurogenetics. 2013; 14(3-4): 243-245.

[56] Tachikawa, M., Kanagawa, M., Yu, C. C., Kobayashi, K., Toda, T. Mislocalization of fukutin protein by disease-causing missense mutations can be rescued with treatments directed at folding amelioration. J Biol Chem. 2012; 287(11): 83988406.

[57] Vuillaumier-Barrot, S., Quijano-Roy, S., Bouchet-Seraphin, C., Maugenre, S., Peudenier, S., Van, den Bergh, P., Marcorelles, P., Avila-Smirnow, D., Chelbi, M., Romero, N. B., Carlier, R. Y., Estournet, B., Guicheney, P., Seta, N. Four Caucasian patients with mutations in the fukutin gene and variable clinical phenotype. Neuromuscul Disord. 2009; 19(3): 182188.

[58] Esapa, C. T., Benson, M. A., Schroder, J. E., Martin-Rendon, E., Brockington, M., Brown, S. C., Muntoni, F., Kroger, S., Blake, D. J. Functional requirements for fukutin-related protein in the Golgi apparatus. Hum Mol Genet. 2002; 11(26): 3319-3331.

[59] Lu, P. J., Zillmer, A., Wu, X., Lochmuller, H., Vachris, J., Blake, D., Chan, Y. M., Lu, Q. L. Mutations alter secretion of fukutin-related protein. Biochim Biophys Acta. 2010; 1802(2): 253-258.

[60] Brockington, M., Yuva, Y., Prandini, P., Brown, S. C., Torelli, S., Benson, M. A., Herrmann, R., Anderson, L. V., Bashir, R., Burgunder, J. M., Fallet, S., Romero, N., Fardeau, M., Straub, V., Storey, G., Pollitt, C., Richard, I., Sewry, C. A., Bushby, K., Voit, T., Blake, D. J., Muntoni, F. Mutations in the fukutin-related protein gene (FKRP) identify limb girdle muscular dystrophy $2 \mathrm{I}$ as a milder allelic variant of congenital muscular dystrophy MDC1C. Hum Mol Genet. 2001; 10(25): 2851-2859.

[61] Beltran-Valero, de Bernabe, D., Voit, T., Longman, C., Steinbrecher, A., Straub, V., Yuva, Y., Herrmann, R., Sperner, J., Korenke, C., Diesen, C., Dobyns, W. B., Brunner, H. G., van Bokhoven, H., Brockington, M., Muntoni, F. Mutations in the FKRP gene can cause muscle-eye-brain disease and Walker-Warburg syndrome. J Med Genet. 2004; 41(5): e61.

[62] Van Reeuwijk, J., Olderode-Berends, M. J., Van den Elzen, C., Brouwer, O. F., Roscioli, T., Van Pampus, M. G., Scheffer, H., Brunner, H. G., Van Bokhoven, H., Hol, F. A. A homozygous FKRP start codon mutation is associated with Walker-Warburg syndrome, the severe end of the clinical spectrum. Clin Genet. 2010; 78(3): 275-281.

[63] Brown, S. C., Torelli, S., Brockington, M., Yuva, Y., Jimenez, C., Feng, L., Anderson, L., Ugo, I., Kroger, S., Bushby, K., Voit, T., Sewry, C., Muntoni, F. Abnormalities in alpha-dystroglycan expression in MDC1C and LGMD2I muscular dystrophies. Am J Pathol. 2004; 164(2): 727-737.

[64] Frosk, P., Greenberg, C. R., Tennese, A. A., Lamont, R., Nylen, E., Hirst, C., Frappier, D., Roslin, N. M., Zaik, M., 
Bushby, K., Straub, V., Zatz, M., de Paula, F., Morgan, K., Fujiwara, T. M., Wrogemann, K. The most common mutation in FKRP causing limb girdle muscular dystrophy type 2I (LGMD2I) may have occurred only once and is present in Hutterites and other populations. Hum Mutat. 2005; 25(1): $38-44$.

[65] Vieira, N. M., Schlesinger, D., de Paula, F., Vainzof, M., Zatz, M. Mutation analysis in the FKRP gene provides an explanation for a rare cause of intrafamilial clinical variability in LGMD2I. Neuromuscul Disord. 2006; 16(12): 870-873.

[66] Willer, T., Lee, H., Lommel, M., Yoshida-Moriguchi, T., de Bernabe, D. B., Venzke, D., Cirak, S., Schachter, H., Vajsar, J., Voit, T., Muntoni, F., Loder, A. S., Dobyns, W. B., Winder T. L., Strahl, S., Mathews, K. D., Nelson, S. F., Moore, S. A., Campbell, K. P. ISPD loss-of-function mutations disrupt dystroglycan O-mannosylation and cause Walker-Warburg syndrome. Nat Genet. 2012; 44(5): 575-580.

[67] Roscioli, T., Kamsteeg, E. J., Buysse, K., Maystadt, I., van Reeuwijk, J., van den Elzen, C., van Beusekom, E., Riemersma, M., Pfundt, R., Vissers, L. E., Schraders, M., Altunoglu, U., Buckley, M. F., Brunner, H. G., Grisart, B., Zhou, H., Veltman, J. A., Gilissen, C., Mancini, G. M., Delree, P., Willemsen, M. A., Ramadza, D. P., Chitayat, D. Bennett, C., Sheridan, E., Peeters, E. A., Tan-Sindhunata, G. M., de Die-Smulders, C. E., Devriendt, K., Kayserili, H., ElHashash, O. A., Stemple, D. L., Lefeber, D. J., Lin, Y. Y., van Bokhoven, H. Mutations in ISPD cause Walker-Warburg syndrome and defective glycosylation of alpha-dystroglycan. Nat Genet. 2012; 44(5): 581-585.

[68] Vuillaumier-Barrot, S., Bouchet-Seraphin, C., Chelbi, M., Devisme, L., Quentin, S., Gazal, S., Laquerriere, A., FalletBianco, C., Loget, P., Odent, S., Carles, D., Bazin, A., Aziza, J., Clemenson, A., Guimiot, F., Bonniere, M., Monnot, S., Bole-Feysot, C., Bernard, J. P., Loeuillet, L., Gonzales, M., Socha, K., Grandchamp, B., Attie-Bitach, T., Encha-Razavi, F., Seta N. Identification of mutations in TMEM5 and ISPD as a cause of severe cobblestone lissencephaly. Am J Hum Genet. 2012; 91(6): 1135-1143.

[69] Breton, C., Snajdrova, L., Jeanneau, C., Koca, J., Imberty, A. Structures and mechanisms of glycosyltransferases. Glycobiology. 2006; 16(2): 29R-37R.

[70] Czeschik, J. C., Hehr, U., Hartmann, B., Ludecke, H. J., Rosenbaum, T., Schweiger, B., Wieczorek, D. $160 \mathrm{~kb}$ deletion in ISPD unmasking a recessive mutation in a patient with Walker-Warburg syndrome. Eur J Med Genet. 2013; 56(12): 689-694.

[71] Cirak, S., Foley, A. R., Herrmann, R., Willer, T., Yau, S., Stevens, E., Torelli, S., Brodd, L., Kamynina, A., Vondracek, P., Roper, H., Longman, C., Korinthenberg, R., Marrosu, G., Nurnberg, P., Michele, D. E., Plagnol, V., Hurles, M., Moore, S. A., Sewry, C. A., Campbell, K. P., Voit, T., Muntoni, F. ISPD gene mutations are a common cause of congenital and limb-girdle muscular dystrophies. Brain. 2013; 136(Pt 1): 269-281.

[72] Baranello, G., Saredi, S., Sansanelli, S., Savadori, P., Canioni, E., Chiapparini, L., Balestri, P., Malandrini, A., Arnoldi, M. T., Pantaleoni, C., Morandi, L., Mora, M. A novel homozygous ISPD gene mutation causing phenotype variability in a consanguineous family. Neuromuscul Disord. 2014.

[73] Lonie, L., Porter, D. E., Fraser, M., Cole, T., Wise, C., Yates, L., Wakeling, E., Blair, E., Morava, E., Monaco, A. P., Ragoussis, J. Determination of the mutation spectrum of the EXT1/EXT2 genes in British Caucasian patients with multiple osteochondromas, and exclusion of six candidate genes in EXT negative cases. Hum Mutat. 2006; 27(11): 1160.
[74] Maeda, Y., Kinoshita, T. Dolichol-phosphate mannose synthase: Structure, function and regulation. Biochim Biophys Acta. 2008; 1780(6): 861-868.

[75] Jaeken J. Congenital disorders of glycosylation (CDG): It's (nearly) all in it! J Inherit Metab Dis. 2011; 34(4): 853-858.

[76] Barone, R., Aiello, C., Race, V., Morava, E., Foulquier, F., Riemersma, M., Passarelli, C., Concolino, D., Carella, M., Santorelli, F., Vleugels, W., Mercuri, E., Garozzo, D., Sturiale, L., Messina, S., Jaeken, J., Fiumara, A., Wevers, R. A., Bertini, E., Matthijs, G., Lefeber, D. J. DPM2-CDG: A muscular dystrophy-dystroglycanopathy syndrome with severe epilepsy. Ann Neurol. 2012; 72(4): 550-558.

[77] Lefeber, D. J., de Brouwer, A. P., Morava, E., Riemersma, M., Schuurs-Hoeijmakers, J. H., Absmanner, B., Verrijp, K., van den Akker, W. M., Huijben, K., Steenbergen, G., van Reeuwijk, J., Jozwiak, A., Zucker, N., Lorber, A., Lammens, M., Knopf, C., van Bokhoven, H., Grunewald, S., Lehle, L., Kapusta, L., Mandel, H., Wevers, R. A. Autosomal recessive dilated cardiomyopathy due to DOLK mutations results from abnormal dystroglycan O-mannosylation. PLoS Genet. 2011; 7(12): e1002427.

[78] Yang, A. C., Ng, B. G., Moore, S. A., Rush, J., Waechter, C. J., Raymond, K. M., Willer, T., Campbell, K. P., Freeze, H. H., Mehta, L. Congenital disorder of glycosylation due to DPM1 mutations presenting with dystroglycanopathy-type congenital muscular dystrophy. Mol Genet Metab. 2013; 110(3): 345-351.

[79] Lefeber, D. J., Schonberger, J., Morava, E., Guillard, M., Huyben, K. M., Verrijp, K., Grafakou, O., Evangeliou, A., Preijers, F. W., Manta, P., Yildiz, J., Grunewald, S., Spilioti, M., van den Elzen, C., Klein, D., Hess, D., Ashida, H., Hofsteenge, J., Maeda, Y., van den Heuvel, L., Lammens, M., Lehle, L., Wevers, R. A. Deficiency of Dol-P-Man synthase subunit DPM3 bridges the congenital disorders of glycosylation with the dystroglycanopathies. Am J Hum Genet. 2009; 85(1): 76-86.

[80] Ning, B., Elbein, A. D. Cloning, expression and characterization of the pig liver GDP-mannose pyrophosphorylase. Evidence that GDP-mannose and GDP-Glc pyrophosphorylases are different proteins. Eur J Biochem. 2000; 267(23): 6866-6874.

[81] Carss, K. J., Stevens, E., Foley, A. R., Cirak, S., Riemersma, M., Torelli, S., Hoischen, A., Willer, T., van Scherpenzeel, M., Moore, S. A., Messina, S., Bertini, E., Bonnemann, C. G., Abdenur, J. E., Grosmann, C. M., Kesari, A., Punetha, J., Quinlivan, R., Waddell, L. B., Young, H. K., Wraige, E., Yau, S., Brodd, L., Feng, L., Sewry, C., MacArthur, D. G., North, K. N., Hoffman, E., Stemple, D. L., Hurles, M. E., van Bokhoven, H., Campbell, K. P., Lefeber, D. J., Lin, Y. Y., Muntoni, F. Mutations in GDP-mannose pyrophosphorylase B cause congenital and limb-girdle muscular dystrophies associated with hypoglycosylation of alpha-dystroglycan. Am J Hum Genet. 2013; 93(1): 29-41.

[82] Raphael, A. R., Couthouis, J., Sakamuri, S., Siskind, C., Vogel, H., Day, J. W., Gitler, A. D. Congenital muscular dystrophy and generalized epilepsy caused by GMPPB mutations. Brain Res. 2014 ; 1575: 66-71.

[83] Koehler, K., Malik, M., Mahmood, S., Giesselmann, S., Beetz, C., Hennings, J. C., Huebner, A. K., Grahn, A., Reunert, J., Nurnberg, G., Thiele, H., Altmuller, J., Nurnberg, P., Mumtaz, R., Babovic-Vuksanovic, D., Basel-Vanagaite, L., Borck, G., Bramswig, J., Muhlenberg, R., Sarda, P., Sikiric, A., Anyane-Yeboa, K., Zeharia, A., Ahmad, A., Coubes, C., Wada, Y., Marquardt, T., Vanderschaeghe, D., Van Schaftingen, E., Kurth, I., Huebner, A., Hubner, C. A. Mutations 
in GMPPA cause a glycosylation disorder characterized by intellectual disability and autonomic dysfunction. Am J Hum Genet. 2013; 93(4): 727-734.

[84] de Lonlay, P., Seta, N., Barrot, S., Chabrol, B., Drouin, V., Gabriel, B. M., Journel, H., Kretz, M., Laurent, J., Le Merrer, M., Leroy, A., Pedespan, D., Sarda, P., Villeneuve, N., Schmitz, J., van Schaftingen, E., Matthijs, G., Jaeken, J., Korner, C., Munnich, A., Saudubray, J. M., Cormier-Daire, V. A broad spectrum of clinical presentations in congenital disorders of glycosylation I: A series of 26 cases. J Med Genet. 2001; 38(1): 14-19.

[85] van Reeuwijk, J., Grewal, P. K., Salih, M. A., Beltran-Valero, de Bernabe, D., McLaughlan, J. M., Michielse, C. B., Herrmann, R., Hewitt, J. E., Steinbrecher, A., Seidahmed, M. Z., Shaheed, M. M., Abomelha, A., Brunner, H. G., van Bokhoven, H., Voit, T. Intragenic deletion in the LARGE gene causes Walker-Warburg syndrome. Hum Genet. 2007; 121(6): 685-690.

[86] Jimenez-Mallebrera, C., Torelli, S., Feng, L., Kim, J., Godfrey, C., Clement, E., Mein, R., Abbs, S., Brown, S. C., Campbell, K. P., Kroger, S., Talim, B., Topaloglu, H., Quinlivan, R., Roper, H., Childs, A. M., Kinali, M., Sewry, C. A., Muntoni, F. A comparative study of alpha-dystroglycan glycosylation in dystroglycanopathies suggests that the hypoglycosylation of alpha-dystroglycan does not consistently correlate with clinical severity. Brain Pathol. 2009, 19(4): 596-611.

[87] Stevens, E., Torelli, S., Feng, L., Phadke, R., Walter, M. C., Schneiderat, P., Eddaoudi, A., Sewry, C. A., Muntoni, F. Flow cytometry for the analysis of alpha-dystroglycan glycosylation in fibroblasts from patients with dystroglycanopathies. PLoS One. 2013; 8(7): e68958.

[88] Lommel, M., Cirak, S., Willer, T., Hermann, R., Uyanik, G., van Bokhoven, H., Korner, C., Voit, T., Baric, I., Hehr, U., Strahl, S. Correlation of enzyme activity and clinical phenotype in POMT1-associated dystroglycanopathies. Neurology. 2010; 74(2): 157-164

[89] Vester-Christensen, M. B., Halim, A., Joshi, H. J., Steentoft, C., Bennett, E. P., Levery, S. B., Vakhrushev, S. Y., Clausen, $\mathrm{H}$. Mining the O-mannose glycoproteome reveals cadherins as major O-mannosylated glycoproteins. Proc Natl Acad Sci U S A. 2013; 110(52): 21018-21023.

[90] Lommel. M., Winterhalter, P. R., Willer, T., Dahlhoff, M., Schneider, M. R., Bartels, M. F., Renner-Muller, I., Ruppert, T., Wolf, E., Strahl, S. Protein O-mannosylation is crucial for E-cadherin-mediated cell adhesion. Proc Natl Acad Sci U S A. 2013; 110(52): 21024-21029. 